Gdynia

\title{
Współpraca państw UE w realizacji polityki akwenowej na przykładzie pierwszej, morskiej, militarnej operacji EUNAVFOR ATALANTA
}

omalia, znajdując się na wschodzie Afryki (na tzw. The Horn of Africa ${ }^{1}$ ), graniczy
z jednym z ważniejszych morskich szlaków komunikacyjnych na Ziemi: Kanał Sueski-Morze Czerwone-Zatoka Adeńska. Szacuje się, że każdego roku ten szlak przemierza ponad 22 tysięce statków przewożących około 8\% światowego transportu morskiego i ponad $12 \%$ transportowanej drogą morską ropy naftowej ${ }^{2}$. Kryzys i destabilizacja, która na przestrzeni ostatnich lat dotknęła Somalię sprzyja rozwojowi przestępczości, w tym również zorganizowanej przestępczości morskiej ${ }^{3}$. Bezpośrednim skutkiem braku silnej, centralnej władzy był wzrost liczby ataków pirackich na jednostki przepływające u wybrzeży Somalii ${ }^{4}$. Perspektywa zdobycia łupów z grabieży jednostek handlowych, porwania jachtów oraz wymuszanie okupów za uwolnienie statku i załogi stała się bardzo kusząca dla przestępców z wybrzeży Somalii. Sytuacja uległa znacznemu pogorszeniu, od czasu kiedy armatorzy porwanych jednostek zaczęli wypłacać ogromne okupy za porwane statki i wzięte do niewoli załogi. Zasoby pieniędzy zdobyte z przestępczości pozwoliły piratom na pozyskanie nowoczesnego sprzętu i wyposażenia zwiększającego szansę zajęcia nawet największych jednostek handlowych, jak również na podsłuchiwanie łączności radiowej i poszukiwanie potencjalnych celów ataków za pomocą nie tylko radarów nawigacyjnych, lecz także systemów pierwotnie używanych do poprawy bezpieczeństwa nawigacji takich jak choćby AIS $^{5}$. W ciagu ostatnich dwóch lat znacznej poprawie uległa organizacja ataków pirackich jak również zwiększyła się ich częstotliwość. Zwiększył się również zasięg działania piratów, którzy zagrażać zaczęli nawet żegludze na wodach międzynarodowych. W rezultacie niepohamowanego wzrostu ataków pirackich dokonywanych z Somalii wschodnie wybrzeże Afryki stało się obszarem, na którym popełniana jest największa część przestępstw dokonywanych na akwenach całego świata.

Unia Europejska, dla której zakłócenie handlu morskiego na szlaku Kanał Sueski-Morze Czerwone-Zatoka Adeńska mogło przynieść szczególnie dotkliwe skutki, aktywnie zaangażowała się w walkę z piractwem u wybrzeży Somalii. Zintensyfikowana działalność piratów

\footnotetext{
${ }^{1}$ The Horn of Africa - Róg Afryki; Półwysep Somalijski.

${ }^{2}$ IMO Report on Piracy in waters off the coast of Somalia, International Maritime Organization, 2009, http://www.imo.org/TCD/mainframe.asp?topic_id=1178, 22.02.2010.

${ }^{3}$ T. Lyons, A. I. Samatar, Somalia State Collapse, Multilateral Intervention, and Strategies for Political Reconstruction, Washington D.C. 1995, s. 25-26.

${ }^{4}$ Somalia, U.S. Department of State Diplomacy In Action, 2010, http://www.state.gov/r/pa/ei/bgn/2863.htm, 23.02.2010.

${ }^{5}$ AIS - Automatic Identification System - System Automatycznej Identyfikacji Statków.
} 
Wykres 1. Liczba potwierdzonych ataków pirackich w Afryce Wschodniej i na pozostałych akwenach świata w kolejnych kwartałach w latach 2007-2009

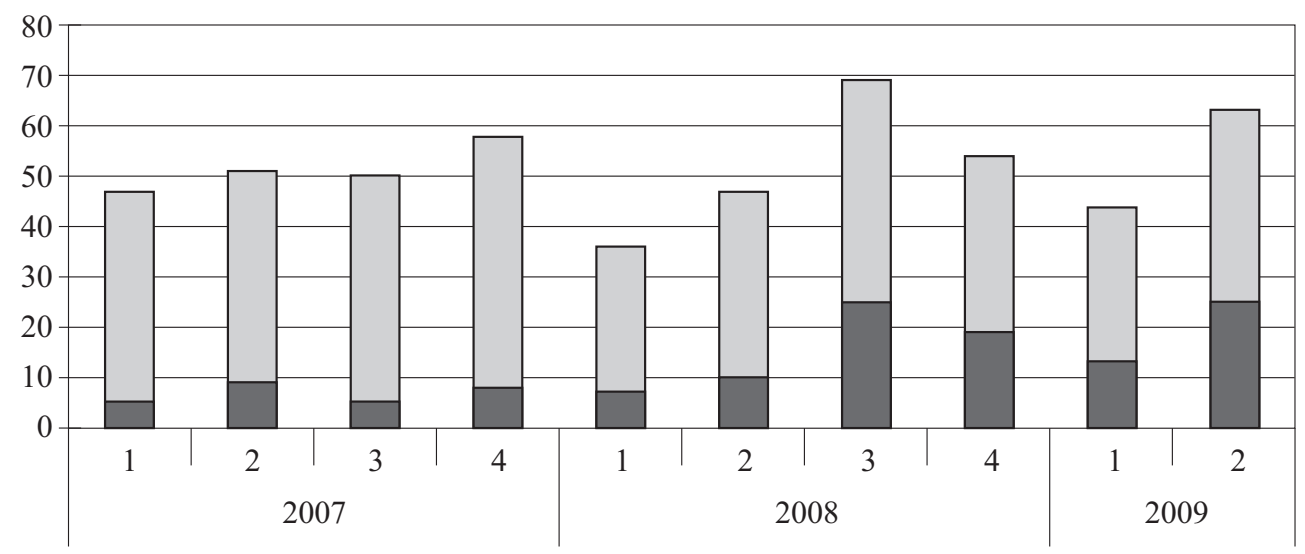

$\square$ wybrzeże Afryki Wschodniej $\square$ pozostałe akweny świata

Źródło: Opracowanie własne na podstawie: IMO Reports on piracy and armed robbery, International Maritime Organization, http://www.imo.org/home.asp?topic_id=334, 22.02.2010.

Wykres 2. Liczba niepotwierdzonych ataków pirackich w Afryce Wschodniej i na pozostałych akwenach świata w kolejnych kwartalach w latach 2007-2009

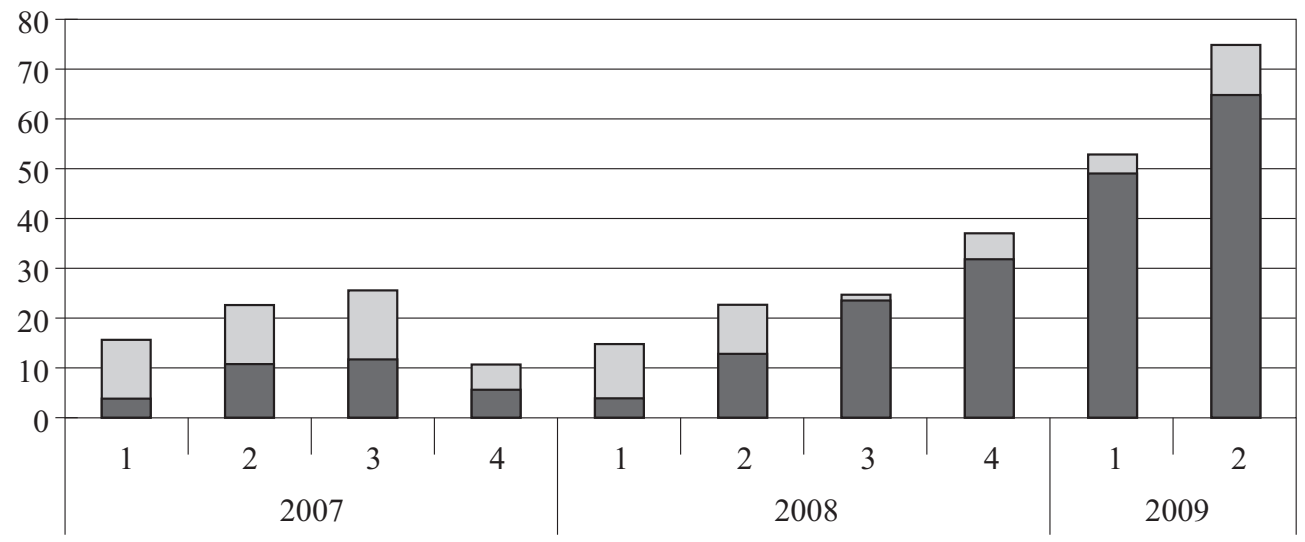

wybrzeże Afryki Wschodniej $\square$ pozostałe akweny świata

Źródło: Opracowanie własne na podstawie: IMO Reports on piracy and armed robbery, International Maritime Organization, http://www.imo.org/home.asp?topic_id=334, 22.02.2010.

u wschodnich wybrzeży Afryki stanowiła również zagrożenie dla wspieranego przez Unię Europejską Światowego Programu Żywnościowego $\left(\mathrm{WFP}^{6}\right.$ ) próbującego załagodzić skutki kryzysu w Somalii. Efektem działań politycznych, organizacyjnych i prawnych było rozpoczęcie pierwszej morskiej militarnej operacji pod egidą Unii Europejskiej nazwaną EUNAVFOR Somalia - Operation ATALANTA.

\footnotetext{
${ }^{6}$ WFP - World Food Programme.
} 
Liczba i miejsce potwierdzonych ataków pirackich dokonanych w Afryce Wschodniej w latach 2007-2009

\begin{tabular}{|c|c|c|c|c|c|c|c|}
\hline \multicolumn{8}{|c|}{ Liczba i miejsce ataków pirackich w Afryce Wschodniej } \\
\hline \multirow[b]{2}{*}{ rok } & \multirow{2}{*}{$\begin{array}{c}\text { kwar- } \\
\text { tał }\end{array}$} & \multicolumn{4}{|c|}{ ataki dokonane i potwierdzone } & \multirow{2}{*}{$\begin{array}{l}\text { ataki usilowane, lecz } \\
\text { niepotwierdzone }\end{array}$} & \multirow[b]{2}{*}{ wszystkie } \\
\hline & & $\begin{array}{l}\text { na wodach mię- } \\
\text { dzynarodowych }\end{array}$ & $\begin{array}{l}\text { na morzu te- } \\
\text { rytorialnym }\end{array}$ & w porcie & razem & & \\
\hline \multirow[t]{4}{*}{2007} & 1 & 1 & 3 & 1 & 5 & 4 & 9 \\
\hline & 2 & 3 & 5 & 1 & 9 & 11 & 20 \\
\hline & 3 & 0 & 3 & 2 & 5 & 12 & 17 \\
\hline & 4 & 3 & 2 & 3 & 8 & 6 & 14 \\
\hline \multirow[t]{4}{*}{2008} & 1 & 2 & 3 & 2 & 7 & 4 & 11 \\
\hline & 2 & 6 & 1 & 3 & 10 & 13 & 23 \\
\hline & 3 & 21 & 4 & 0 & 25 & 24 & 49 \\
\hline & 4 & 19 & 0 & 0 & 19 & 32 & 51 \\
\hline \multirow[t]{2}{*}{2009} & 1 & 8 & 4 & 1 & 13 & 49 & 62 \\
\hline & 2 & 21 & 3 & 1 & 25 & 65 & 90 \\
\hline
\end{tabular}

Źródło: Opracowanie własne na podstawie: IMO Reports on piracy and armed robbery, International Maritime Organization, http://www.imo.org/home.asp?topic_id=334, 22.02.2010.

Prawną podstawę dla międzynarodowej operacji ATALANTA stanowi Konwencja Narodów Zjednoczonych o Prawie Morza sporządzona w Montego Bay dnia 10 grudnia 1982 r. oraz rezolucje Rady Bezpieczeństwa ONZ:

- 1814 z dnia 15 maja 2008 r.;

- 1816 z dnia 2 czerwca 2008 r.;

- 1838 z dnia 7 października 2008 r.;

- 1846 z dnia 2 grudnia $2008 \mathrm{r}$.

W rezolucji 1816 Rady Bezpieczeństwa ONZ, Sekretarz Rady Bezpieczeństwa wezwał kraje, w których interesie leży bezpieczne korzystanie z dróg morskich przy wybrzeżu Somalii, do zwiększonych, skoordynowanych działań na rzecz powstrzymania piractwa i zbrojnych napadów na jednostki handlowe na morzu przy współpracy z Tymczasowym Rządem Somalii $\left(\mathrm{TFG}^{7}\right)$. Państwa współpracujące z Tymczasowym Rządem Somalii uzyskały pozwolenie na wejście na morze terytorialne Somalii oraz użycie wszelkich dostępnych środków do stłumienia aktów piractwa i zbrojnych napadów na morzu ${ }^{8}$.

Dnia 5 sierpnia 2008 r. Rada Unii Europejskiej zaakceptowała koncepcję wprowadzenia w życie rezolucji 1816 Rady Bezpieczeństwa ONZ z 2 czerwca 2008 r. Już 19 września 2008 r. Rada Unii Europejskiej zatwierdziła przeprowadzenie skoordynowanej operacji militarnej nazwanej EU NAVCO oraz powołała komórkę organizacyjną (EU Coordination Cell) i jej przewodniczącego komandora Andresa A. Breijo Claur'. W dniu 10 listopada 2008 r. na forum Rady UE oficjalnie powołano do życia pierwszą morską militarną operację Unii Europejskiej, którą nazwano ATALANTA. Decyzja określiła również główne cele operacji, którymi

\footnotetext{
${ }^{7}$ TFG - Transitional Federal Government of Somalia.

${ }^{8}$ Resolution 1816 (2008), Rada Unii Europejskiej, 2008, http://www.consilium.europa.eu/uedocs/cmsUpload/N0836177.pdf, 22.02.2010.

${ }^{9}$ Council Joint Action 2008/749/CFSP, Rada Unii Europejskiej, 2008, http://eur-lex.europa.eu/LexUriServ/LexUriServ.do?uri=OJ:L:2008:252:0039:0042:EN:PDF, 22.02.2010.
} 
miały być ochrona jednostek Światowego Programu Żywnościowego oraz ochrona żeglugi i powstrzymywanie piractwa i zbrojnych napadów, zgodnie z rezolucją 1814 i 1816 Rady Bezpieczeństwa ONZ ${ }^{10}$. Ustalono również rejon działania sił morskich UE, który stanowił obszar do $500 \mathrm{Mm}$ od brzegu Somalii i państw sąsiednich oraz powołano pierwszego Dowódcę Sił Operacyjnych Unii Europejskiej, którym został kontr adm. Phillip Jones. Komitet Polityczny i Bezpieczeństwa Unii Europejskiej decyzją z 18 listopada 2008 r. powołał Dowódcę Sił Unii Europejskiej, którym został komodor Antonious Papaioannou ${ }^{11}$. Oficjalne rozpoczęcie operacji ATALANTA nastąiło wraz z wydaniem decyzji 2008/918/CFSP przez Komitet Polityczny i Bezpieczeństwa Unii Europejskiej dnia 8 grudnia 2008 r. $^{12}$

Koszt przygotowania operacji ATALANTA wyniósł 60000 euro $^{13}$, zaś budżet samej operacji ustalony został na 8,3 mln euro. Zgodnie z artykułem 28(3) traktatu z Maastricht koszty operacji UE mających skutki militarne lub obronne pokrywane są przez państwa członkowskie na podstawie ich $\mathrm{PKB}^{14}$. W związku z powyższym wszystkie kraje Wspólnoty z wyłączeniem Królestwa Danii, które zgodnie z artykułem 6 aneksu do traktatu z Maastricht nie bierze udziału w decyzjach dotyczących sfery obronności Wspólnoty ${ }^{15}$, współfinansują morską misję ATALANTA. Budżet operacji przeznaczony jest głównie na pokrycie kosztów działania Dowództwa Operacyjnego i Dowództwa Sił Unii Europejskiej, zaś koszty utrzymania załóg, jednostek uczestniczących w operacji oraz ich zaopatrzenia i logistyki pokrywają państwa kierujące swoje siły pod wspólne dowództwo operacji ATALANTA.

Operacja ATALANTA prowadzona jest z ramienia Rady Europejskiej i podlega pod Komitet Polityczny i Bezpieczeństwa Unii Europejskiej. Działający w ramach Europejskiej Polityki Bezpieczeństwa i Obrony Komitet Wojskowy Unii Europejskiej, któremu przewodniczy generał Håkan Syrén, odpowiedzialny jest za monitorowanie wykonywania misji zgodnie Z wytycznymi Rady Europejskiej ${ }^{16}$.

Dowództwo Operacyjne EUNAVFOR Somalia - Operation ATALANTA znajduje się w Northwood w Wielkiej Brytanii, zaś Dowództwo Sił Unii Europejskiej znajduje się na flagowym okręcie w rejonie działania floty. Pierwszym dowódcą operacyjnym został brytyjski kontradm. Phillip Jones, zaś 3 czerwca 2009 r. zastąpił go jego rodak kontradm. Peter Hudson, który swoją funkcję sprawuje do dnia dzisiejszego ${ }^{17}$. Siły Unii Europejskiej podczas całego okresu trwania operacji składały się z 10-12 okrętów, w tym okrętów podwodnych

${ }^{10}$ Council Joint Action 2008/749/CFSP 2008/851/CFSP, Rada Unii Europejskiej, 2008, http://eur- -22lex.europa.eu/LexUriServ/LexUriServ.do?uri=OJ:L:2008:301:0033:0037:EN:PDF, 22.02.2010.

${ }^{11}$ Political and security committee decision Atalanta1/2008, EUR-lex, 2008, http://eur-lex.europa.eu/LexUriServ/LexUriServ.do?uri=OJ:L:2008:317:0024:0024:EN:PDF, 22.02.2010.

${ }^{12}$ Council Decision 2008/918/CFSP, EUR-lex, 2008, http://eur-lex.europa.eu/LexUriServ/LexUriServ.do?uri= OJ:L:2008:330:0019:0020:EN:PDF, 22.02.2010.

${ }^{13}$ Council Joint Action 2008/749CFSP, EUR-lex, 2008, http://eur-lex.europa.eu/LexUriServ/LexUriServ.do?uri=OJ:L:2008:252:0039:0042:EN:PDF, 22.02.2010.

${ }^{14}$ EU Naval operations against Piracy (EUNAVFOR Somalia-Operation ATALANTA), Rada Unii Europejskiej, 2009, http://www.consilium.europa.eu/uedocs/cms_data/docs/missionPress/files/091117\%20Factsheet $\% 20$ EU\%20NAVFOR\%20Somalia\%20-\%20version\%2012_EN.pdf, 22.02.2010.

${ }^{15}$ Council Joint Action 2008/749CFSP, EUR-lex, 2008, http://eur-lex.europa.eu/LexUriServ/LexUriServ.do?uri=OJ:L:2008:252:0039:0042:EN:PDF, 22.02.2010.

${ }^{16}$ EU Naval operations against Piracy (EUNAVFOR Somalia-Operation ATALANTA), Rada Unii Europejskiej, 2009, http://www.consilium.europa.eu/uedocs/cms_data/docs/missionPress/files/091117\%20Factsheet\%20EU\%20NAVFOR\%20Somalia\%20-\%20version\%2012_EN.pdf, 22.02.2010.

${ }^{17}$ Javier SOLANA, EU High Representative for the CFSP, congratulates Rear Admiral HUDSON on taking office as EU Operation Commander of Operation EU NAVFOR - ATALANTA, Rada Unii Europejskiej, 2009, http://www.consilium.europa.eu/uedocs/cms_data/docs/pressdata/EN/declarations/108239.pdf, 22.02.2010. 
oraz kilku statków powietrznych. Liczba żołnierzy i personelu zaangażowanego w działania operacyjne wynosi około 1800 osób $^{18}$.

Tabela 2

Wykaz okrętów sił Unii Europejskiej biorących udział w operacji ATALANTA w listopadzie 2009 r.

\begin{tabular}{|c|c|c|}
\hline Nazwa & Klasa & Państwo \\
\hline SPS Canarias (F86) & Fregata klasy Santa Maria & Hiszpania \\
\hline FGS Bremen (F207) & Fregata klasy Bremen & Niemcy \\
\hline FGS Karlsruhe (F212) & Fregata klasy Bremen & Niemcy \\
\hline La Fayette (F710) & Fregata klasy La Fayette & Francja \\
\hline Germinal (F735) & Fregata klasy Floréal & Francja \\
\hline Floréal (F730) & Fregata klasy Floréal & Francja \\
\hline Améthyste (S605) & OP klasy Rubis & Francja \\
\hline HRMS Evertsen & Fregata klasy De Zeven Provinciën & Holandia \\
\hline Adrias (F459) & Fregata klasy Elli & Grecja \\
\hline FGS Louise-Marie & Fregata klasy Karel Doorman & Belgia \\
\hline Etna (A 4326) & Okręt zaopatrzeniowy klasy Etna & Włochy \\
\hline
\end{tabular}

Źródło: Opracowanie własne na podstawie: Current Total strength of EU-NAVFOR ATALANTA, Rada Unii Europejskiej, http://www.consilium.europa.eu/uedocs/cmsUpload/naviresOCTOBRE.pdf, 22.02.2010.

Wykaz dowódców sil Unii Europejskiej, ich okrętów flagowych i okresów kierowania silami EUNAVFOR Somalia - Operation ATALANTA

\begin{tabular}{||l|l|l|l||}
\hline Okres kierowania silami EU & \multicolumn{1}{|c|}{ Dowódca sil UE } & Okręt flagowy & \multicolumn{1}{c||}{ Państwo } \\
\hline $08.12 .2008-06.04 .2009$ & komodor Antonious Papaioannou & PSARA & Grecja \\
\hline $06.04 .2009-13.08 .2009$ & kmdr Juan Garat Carame & NUMANCIA & Hiszpania \\
\hline $13.08 .2009-13.12 .2009$ & komodor Pieter Bindt & EVERTSEN & Holandia \\
\hline $13.12 .2009-$ do chwili obecnej & wiceadmirał Giovanni Gumiero & ETNA & Włochy \\
\hline \hline
\end{tabular}

Źródło: Opracowanie własne na podstawie: EU NAVFOR - ATALANTA CHANGE OF COMMAND AT FORCE HEADQUARTERS, Rada Unii Europejskiej, http://www.consilium.europa.eu/uedocs/cms_Data/docs/pressdata/en/esdp/107163.pdf, 22.02.2010 oraz Javier SOLANA, EU High Representative for the CFSP, congratulates Commodore Pieter BINDT on taking office as EU Force Commander of EU NAVFOR Somalia, Rada Unii Europejskiej, http://www.consilium.europa.eu/ueDocs/cms_Data/docs/pressdata/en/declarations/109661.pdf, 22.02.2010.

Morska operacja Unii Europejskiej byłaby niemożliwa bez współpracy i uzgodnień z przedstawicielami władzy samej Somalii. Umowa pomiędzy Unią Europejską a Somalią o statusie sił morskich Wspólnoty działających w ramach operacji ATALANTA została podpisana 31 grudnia 2008 roku w Nairobi. Umowa określiła zasady działania sił Unii Europejskiej na morzu terytorialnym i terytorium Somalii oraz dała znaczny wachlarz przywilejów samym siłom, jak i ich personelowi ${ }^{19}$.

${ }^{18}$ EU Naval operations against Piracy (EUNAVFOR Somalia-Operation ATALANTA), Rada Unii Europejskiej, 2009, http://www.consilium.europa.eu/uedocs/cms_data/docs/missionPress/files/091117\%20Factsheet $\% 20$ EU\%20NAVFOR\%20Somalia\%20-\%20version\%2012_EN.pdf, 22.02.2010.

19 AGREEMENT between the European Union and the Somali Republic on the status of the European Union-led naval force in the Somali Republic in the framework of the EU military operation Atalanta, EUR-lex, 2009, http://eur-lex.europa.eu/LexUriServ/LexUriServ.do?uri=OJ:L:2009:010:0029: 0034:EN:PDF, 22.02.2010. 
W celu zabezpieczenia działania sił morskich w ramach operacji ATALANTA Unia Europejska podpisała również umowę określającą funkcjonowanie jej personelu i sił na terytorium Dżibuti. Dżibuti jest krajem, w którym Francja, będąca jednym z głównych współtwórców operacji ATALANTA, ma stałą bazę wojskową. Prawdopodobnie ten fakt oraz położenie geograficzne Dżibuti przy północnej granicy z Somalią były głównymi przyczynami, które przesądziły o wyborze tego państwa na bazę logistyczną operacji ATALANTA ${ }^{20}$. Do sygnowania porozumienia pomiędzy Wspólnotą a północnym sąsiadem Somalii doszło 5 stycznia 2009 r. w Dżibuti ${ }^{21}$.

Realizując główne zadanie - walkę z piractwem - Siły Unii Europejskiej w czasie trwania operacji wielokrotnie zatrzymywały osoby podejrzane o piractwo lub przyłapane na próbie zbrojnej napaści na statki. Zatrzymanie osób, nieposiadających obywatelstwa żadnego z państw Unii Europejskiej lub nawet nieprzyznających się do żadnego obywatelstwa, zwłaszcza na wodach międzynarodowych, stwarzało wiele problemów prawnych. Zgodnie z artykułem 12 decyzji Komitetu Politycznego i Bezpieczeństwa Unii Europejskiej 2008/851/CFSP z 10 listopada $2008 \mathrm{r}$. zatrzymane osoby podejrzane o piractwo powinny zostać przetransportowane na proces do państwa, którego załoga zatrzymała podejrzanych. W przypadku kiedy dane państwo nie wyrazi chęci podjęcia się takiego działania, osoby te mogą być przekazane innemu państwu ${ }^{22}$. Ze względu na koszta i zabezpieczenie logistyczne transportu zatrzymanych do krajów Unii Europejskiej oraz częsty brak prawnych możliwości osądzania takich osób w samej Wspólnocie niewiele państw godziło się na osądzanie podejrzanych o piractwo. Powstały problem zagrażał realizacji głównych celów operacji bowiem zdarzało się, że zatrzymanym piratom konfiskowano tylko broń i sprzęt, zaś ich samych puszczano wolno. Również skuteczność somalijskiego wymiaru sprawiedliwości, który osądzał osoby podejrzane o przestępstwa na morzu często była wątpliwa. Skala problemu została ujawniona między innymi w rezolucji 1851 Rady Bezpieczeństwa ONZ z dnia 16 grudnia 2008 r. Stwierdzono w niej, że w wyniku problemu z uwarunkowaniami prawnymi, a często również w wyniku braku posiadanych możliwości, osoby zatrzymane w związku z popełnieniem aktu piractwa lub o nie podejrzane są często wypuszczane na wolność ${ }^{23}$. W konwencji zwrócono uwagę, by w takich przypadkach powoływać się na Konwencję o przeciwdziałaniu bezprawnym czynom przeciwko bezpieczeństwu żeglugi morskiej ${ }^{24}$. W celu szybkiego rozwiązania problemu Unia Europejska 6 marca 2009 r. podpisała porozumienie z Kenią, na mocy którego schwytane osoby podejrzane o piractwo mogą być przekazywane władzom Kenii ${ }^{25}$. Podobne porozumienie zo-

\footnotetext{
${ }^{20}$ Atalanta mission against piracy, European Parliament, 2009, http://www.europarl.europa.eu/ eng-internet-publisher/eplive/expert/shotlist.do?reference=20090122SHL46872\&language=en, 22.02.2010.

${ }^{21}$ AGREEMENT between the European Union and the Republic of Djibouti on the status of the European Union-led forces in the Republic of Djibouti in the framework of the EU military operation Atalanta, EUR-lex, 2009, http:/eur-lex.europa.eu/LexUriServ/LexUriServ.do?uri=OJ:L:2009:033:0043:0048:EN:PDF, 22.02.2010.

${ }^{22}$ Council Joint Action 2008/851/CFSP, Rada Unii Europejskiej, 2008, http://eur-lex.europa.eu/LexUriServ/LexUriServ.do?uri=OJ:L:2008:301:0033:0037:EN:PDF, 22.02.2010.

${ }^{23}$ Resolution 1851 (2008), Rada Unii Europejskiej, 2008, http://www.consilium.europa.eu/uedocs/cmsUplo$\mathrm{ad} / \mathrm{N} 0865501 . \mathrm{pdf}, 22.02 .2010$.

${ }^{24}$ Convention for the Suppression of Unlawful Acts Against the Safety of Maritime Navigation, International Maritime Organization, Rzym, 1988, http://www.imo.org/Conventions/mainframe.asp?topic_id=259\&doc_id=686, 22.02.2010.

${ }^{25}$ Exchange of Letters between the European Union and the Government of Kenya on the conditions and modalities for the transfer of persons suspected of having committed acts of piracy and detained by the European Union-led naval force (EUNAVFOR), and seized property in the possession of EUNAVFOR, from EUNAVFOR to Kenya and for their treatment after such transfer, EUR-lex, 2009, http://eur-lex.europa.eu/LexUriServ/LexUriServ.do?uri=OJ:L:2009: 079:0049:0059:EN:PDF, 22.02.2010.
} 
stało podpisane 30 października 2009 r. z władzami Seszeli. Na początku grudnia 2009 r. współpraca Unii Europejskiej z Republiką Seszeli zaowocowała obustronnymi uzgodnieniami dotyczącymi warunków i sposobu transferu osób podejrzanych o piractwo lub zbrojną napaść na statki handlowe na Seszele ${ }^{26}$. Dzięki temu porozumieniu możliwe stało się szybsze i skuteczniejsze doprowadzanie oskarżonych o piractwo przed oblicze sprawiedliwości. Prawdopodobnie, również dzięki skali zaangażowania państw europejskich w operację ATALANTA, ONZ w niedługim czasie zobowiązało się podjąć próby kompleksowego rozwiązania problemu schwytanych piratów, w taki sposób, by ich czyny nie mogły uchodzić bezkarnie.

Tworząc podstawy prawne operacji ATALANTA Unia Europejska założyła, że udział w misji będą mogły brać również okręty państw niebędących członkami Wspólnoty. Pierwszym państwem, spoza Unii Europejskiej, które już w lutym 2009 r. wyraziło wolę wzięcia udziału w operacji ATALANTA była Norwegia. W sierpniu 2009 r. na mocy ustaleń pomiędzy UE i Norwegią pierwszy norweski okręt HNoMS Fridtjof Nansen przybył na Zatokę Adeńską i rozpoczął współpracę z siłami Unii Europejskiej ${ }^{27}$. Norweska fregata do lutego wchodziła w skład sił działających w ramach operacji ATALANTA i aktywnie uczestniczyła w patrolowaniu wybrzeża Somalii.

Norwegia nie jest jedynym państwem, które wyraziło chęć współpracy z siłami Unii Europejskiej w ramach operacji ATALANTA. Chorwacja 27 lipca 2009 r. podpisała porozumienie z Unią Europejska, na mocy którego jej okręty mogą uczestniczyć w operacji na tych samych prawach co okręty Wspólnoty ${ }^{28}$. W dokumencie Komitetu Politycznego i Bezpieczeństwa UE z dnia 2 października 2009 r. określającym udział państw trzecich w operacji ATALANTA znaleźć możemy jeszcze Czarnogórę. Niewiele jednak wiadomo o zamiarach i sposobie uczestnictwa tego państwa w największej, międzynarodowej, antypirackiej misji.

Siły Unii Europejskiej działające u wybrzeży Somalii stale współpracują z innym siłami szerokiej antypirackiej koalicji, wśród której można wymienić grupę operacyjną Stanów Zjednoczonych CTF-151 ${ }^{29}$, południowokoreańską Naval Escort Task Group, marynarkę wojenną NATO - SNMG1 ${ }^{30}$, Rosji, Chin, Malezji i Indii.

W celu skoordynowania ochrony jednostek handlowych przed piratami na akwenach, które zostały włączone w strefę działania operacji ATALANTA stworzono Maritime Security Center - Horn of Africa (MSCHOA). Organizacja ta ma za zadanie ułatwić nawiązanie kontaktu pomiędzy armatorami lub kapitanami statków handlowych a dowództwem Sił Unii Europejskiej w celu zapewnienia jak najwyższego poziomu ochrony. Ponadto, MSCHOA zapewnia załodze cenne informacje, jak postępować, by uniknąć ataku pirackiego, jakie czynności przedsięwziąć podczas napaści i co robić, w przypadku wdarcia się piratów na pokład jednostki, a nawet w czasie odbijania jednostki przez grupy antyterrorystów.

\footnotetext{
${ }^{26}$ Council Decision 2009/877/CFSP, EUR-lex, 2009, http://eur-lex.europa.eu/LexUriServ/ LexUriServ.do?uri= OJ:L:2009:315:0035:0036:EN:PDF, 22.02.2010.

${ }^{27}$ Fighting pirates in EU operation, Norway mission to the EU, 2009, http://www.eu-norway.org/news1/frigate/, 22.02.2010.

${ }^{28}$ AGREEMENT between the European Union and the Republic of Croatia on the participation of the Republic of Croatia in the European Union military operation to contribute to the deterrence, prevention and repression of acts of piracy and armed robbery off the Somali coast (Operation Atalanta), EUR-lex, 2009, http://eur-lex.europa.eu/LexUriServ/LexUriServ.do?uri=OJ:L:2009:202: 0084:0089:EN:PDF, 22.02.2010.

${ }^{29}$ Combined Task Force 151 - grupa operacyjna Stanów Zjednoczonych.

${ }^{30}$ SNMG1 - The Standing NATO Maritime Group (Stała Morska Grupa NATO).
} 
W najbardziej zagrożonym na ataki piratów rejonie - Zatoce Adeńskiej w ramach operacji ATALANTA został wyznaczony międzynarodowy korytarz tranzytowy (IRTC ${ }^{31}$ ). Międzynarodowy korytarz tranzytowy został wyznaczony od wyjścia z Zatoki Bab-el-Mandeb na pozycji $\varphi=11^{\circ} 50^{\prime} \mathrm{N}, \lambda=045^{\circ} 00^{\prime} \mathrm{E}$, zaś kończy się na pozycji $\varphi=14^{\circ} 20^{\prime} \mathrm{N}, \lambda=053^{\circ} 00^{\prime} \mathrm{E}$. IRTC składa się z dwóch torów, jeden w kierunku Oceanu Indyjskiego, drugi w kierunku Morza Czerwonego o szerokości około $5 \mathrm{Mm}$ każdy rozdzielonych pasem o szerokości około $2 \mathrm{Mm}$. Jednostkom zamierzającym przemieszczać się przez Zatokę Adeńską zaleca się, by za pośrednictwem MSCHOA ustaliły optymalne prędkości oraz czasy przejścia, a także by ich przejście odbywało się w grupach tranzytowych $\left(\mathrm{GOA} \mathrm{GT}^{32}\right)$. Rejestrując swoje przejście w MSCHOA oraz dostosowując parametry swojej podróży do zaleceń podanych przez koordynatorów działających z ramienia Wspólnoty jednostki handlowe pomagają maksymalnie skoordynować działania sił morskich UE, przez co również zwiększają własne bezpieczeństwo.

Realizując jedno z głównych zadań - ochronę Światowego Programu Żywnościowego w okresie od 8 grudnia 2008 r. do 13 listopada 2009 r. siły Unii Europejskiej przeprowadziły 51 zadań eskorty statków dostarczających żywność do Somalii ${ }^{33}$. Ponadto, morskie siły Wspólnoty na bieżąco poprawiają bezpieczeństwo żeglugi statków na morskim szlaku Kanał Sueski-Morze Czerwone-Zatoka Adeńska poprzez organizowanie ochrony grup tranzytowych i patrolowanie zagrożonych piractwem akwenów. Niestety pomimo działań morskich

Wykres 3. Liczba i efekt ataków pirackich w Afryce Wschodniej w kolejnych kwartalach w latach 2007-2009

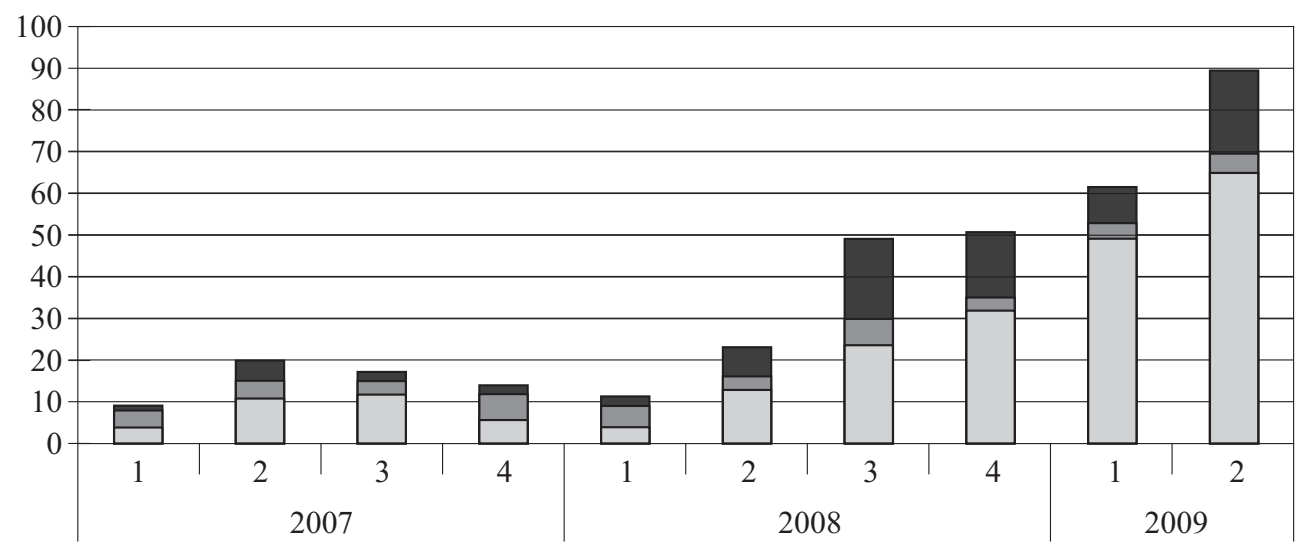

zakończone porwaniem jednostki

$\square$ dokonane, lecz nie zakończone porwaniem jednostki

Źródło: Opracowanie własne na podstawie: IMO Reports on piracy and armed robbery, International Maritime Organization, http://www.imo.org/home.asp?topic_id=334, 22.02.2010.

${ }^{31}$ IRTC - Internationally Recommended Transit Corridor (Międzynarodowy korytarz tranzytowy).

${ }^{32}$ GOA GT - Gulf of Aden Group Transit - grupa tranzytowa składająca się z kilku jednostek handlowych koordynowanych przez MSCHOA, które w zbliżonym czasie przemierzają Zatokę Adeńską międzynarodowym korytarzem tranzytowym.

${ }^{33}$ EU Naval operations against Piracy (EUNAVFOR Somalia-Operation ATALANTA), Rada Unii Europejskiej, 2009, http://www.consilium.europa.eu/uedocs/cms_data/docs/missionPress/files/091117\%20Factsheet\%20EU\%20NAVFOR\%20Somalia\%20-\%20version\%2012_EN.pdf, 22.02.2010. 


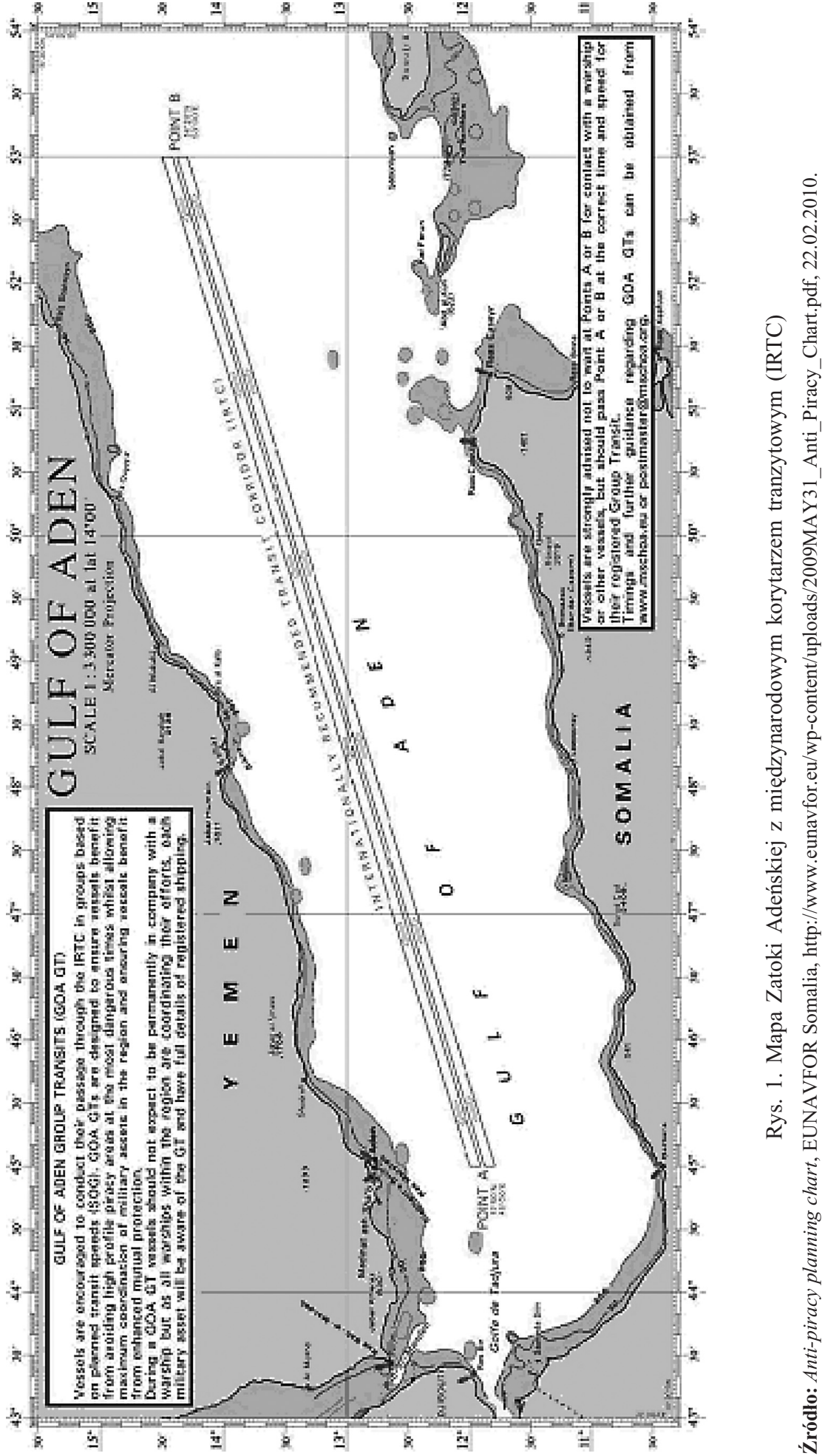


sił Unii Europejskiej nasilenie aktów piractwa i zbrojnych ataków na statki nie maleje, lecz rośnie w zatrważającym tempie.

Ataki piratów stają się coraz bardziej brutalne, zuchwałe i coraz więcej z nich, pomimo obecności sił koalicji antypirackiej, kończy się porwaniem napadniętej jednostki. Rozszerza się również zasięg działalności piratów, zagrażając już nie tylko jednostkom przepływającym przy wybrzeżu Somalii, lecz nawet znacznie od niego oddalonym. Plaga piractwa sięga już nawet jednostek rybackich poławiających w rejonie Seszeli ${ }^{34}$. Nie dziwi zatem fakt, że choć zgodnie z początkowymi założeniami operacja ATALANTA trwać miała 12 miesięcy ${ }^{35}$, zatem do 12 grudnia 2009 r. to jednak w związku z dużym nasileniem aktów piractwa i zbrojnych napadów na statki przepływające w rejonie Somalii Rada Europejska przedłużyła mandat operacji o kolejne 12 miesięcy ${ }^{36}$.

Niespotykana dotąd skala aktów pirackich przy wybrzeżu Somalii wskazuje jednoznacznie, że władze państwowe od wielu lat są zbyt słabe, aby sprawować realną kontrolę nad swoim terytorium ${ }^{37}$. Kryzys i destabilizacja kraju sprzyja działalności przestępczej zarówno na lądzie, jak i na morzu. Choć działania sił UE w ramach operacji ATALANTA na pewno są inhibitorem dla bezprawnych czynów popełnianych na morzu, to jednak bez wzmocnienia władzy, stabilizacji regionu oraz zlikwidowania zaplecza, jakim dysponują przestępcy morscy na lądzie walka z piractwem przybierze charakter usuwania skutków, a nie przyczyn. Mandat morskiej operacji Unii Europejskiej ATALANTA nie obejmuje jednak działań lądowych, prawdopodobnie bez których niemożliwe będzie zatrzymanie plagi piratów.

\section{Bibliografia}

Hashim A. B., The Fallen State: Dissonance, Dictatorship and Death in Somalia, University Press of America, Washington D.C. 1997.

Millien J., State failure, collapse \& reconstruction, Institute of Social Studies, Malden 2003.

Lyons T., Samatar A. I., Somalia State Collapse, Multilateral Intervention, and Strategies for Political Reconstruction, The Booking Institution, Washington D.C. 1995.

Rotberg R. I., State failure and State weakness in a time of terror, The World Peace Foundation, Washington D.C. 2003

AGREEMENT between the European Union and the Republic of Croatia on the participation of the Republic of Croatia in the European Union military operation to contribute to the deterrence, prevention and repression of acts of piracy and armed robbery off the Somali coast (Operation Atalanta), EUR-lex, 2009, http://eur-lex.europa.eu/LexUriServ/LexUriServ.do?uri=OJ:L:2009:202:0084:0089:EN:PDF.

AGREEMENT between the European Union and the Somali Republic on the status of the European Union-led naval force in the Somali Republic in the framework of the EU military operation Atalanta, EUR-lex, 2009, http://eur-lex.europa.eu/LexUriServ/LexUriServ.do?uri=OJ:L:2009:010:0029:0034:EN:PDF.

AGREEMENT between the European Union and the Republic of Djibouti on the status of the European Union-led forces in the Republic of Djibouti in the framework of the EU military operation Atalanta, EUR-lex, 2009, http://eur-lex.europa.eu/LexUriServ/LexUriServ.do?uri=OJ:L:2009:033:0043: 0048:EN:PDF.

Anti-piracy planning chart, EUNAVFOR Somalia, 2009, http://www.eunavfor.eu/wp-content/uploads/2009MAY31_Anti_Piracy_Chart.pdf.

\footnotetext{
${ }^{34}$ Pirates capture Spanish fishing vessel, Rada Unii Europejskiej, 2009, http://www.consilium.europa.eu/App/Article/Article.aspx?article_id=317\&page_id=1518\&type=1\&lang=en\&id=1567, 22.02.2010.

${ }^{35}$ COUNCIL JOINT ACTION 2008/851/CFSP, EUR-lex, 2008, http://eur-lex.europa.eu/LexUriServ/LexUriServ.do?uri=OJ:L:2008:301:0033:0037:EN:PDF, 22.02.2010.

${ }^{36}$ Council conclusions on Operation ATALANTA/EUNAVFOR, Rada Unii Europejskiej, 2009, http://www.consilium.europa.eu/uedocs/cms_data/docs/missionPress/files/Atalanta-EUNAVFOR_EN.pdf, 22.02.2010.

${ }^{37}$ R. I. Rotberg, State failure and State weakness in a time of terror, Washington D.C., 2003, s. 133-134.
} 
Atalanta mission against piracy, European Parliament, 2009, http://www.europarl.europa.eu/eng-internet-publisher/eplive/expert/shotlist.do?reference $=20090122$ SHL46872\&language $=$ en.

Convention for the Suppression of Unlawful Acts Against the Safety of Maritime Navigation, International Maritime Organization, Rzym 1988, http://www.imo.org/Conventions/mainframe.asp?topic_id=259\&doc_id=686.

Council conclusions on Operation ATALANTA/EUNAVFOR, Rada Unii Europejskiej, 2009, http://www.consilium.europa.eu/uedocs/cms_data/docs/missionPress/files/Atalanta-EUNAVFOR_EN.pdf.

Council Decision 2008/918/CFSP, EUR-lex, 2008, http://eur-lex.europa.eu/LexUriServ/LexUriServ.do?uri= OJ:L:2008:330:0019:0020:EN:PDF.

Council Joint Action 2008/749/CFSP, EUR-lex, 2008, http://eur-lex.europa.eu/LexUriServ/LexUriServ.do?uri= OJ:L:2008:252:0039:0042:EN:PDF.

Council Joint Action 2008/749/CFSP, EUR-lex, 2008, http://eur-22lex.europa.eu/LexUriServ/LexUriServ.do?uri= OJ:L:2008:301:0033:0037:EN:PDF.

Council Joint Action 2008/851/CFSP, EUR-lex, 2008, http://eur-lex.europa.eu/LexUriServ/LexUriServ.do?uri= OJ:L:2008:301:0033:0037:EN:PDF.

Council Decision 2009/877/CFSP, EUR-lex, 2009, http://eur-lex.europa.eu/LexUriServ/LexUriServ.do?uri= OJ:L:2009:315:0035:0036:EN:PDF.

Current Total strength of EU-NAVFOR ATALANTA, Rada Unii Europejskiej, 2009, http://www.consilium.europa.eu/uedocs/cmsUpload/naviresOCTOBRE.pdf.

EU High Representative for the CFSP, congratulates Commodore Pieter BINDT on taking office as EU Force Commander of EU NAVFOR Somalia, Rada Unii Europejskiej, 2009, http://www.consilium.europa.eu/ueDocs/cms_Data/docs/pressdata/en/declarations/109661.pdf.

EU Naval operations against Piracy (EUNAVFOR Somalia - Operation ATALANTA), Rada Unii Europejskiej, 2009, http://www.consilium.europa.eu/uedocs/cms_data/docs/missionPress/files/091117\%20Factsheet $\% 20$ EU\%20NAVFOR\%20Somalia\%20-\%20version\%2012_EN.pdf.

EU NAVFOR - ATALANTA CHANGE OF COMMAND AT FORCE HEADQUARTERS, Rada Unii Europejskiej, 2009, http://www.consilium.europa.eu/uedocs/cms_Data/docs/pressdata/en/ esdp/107163.pdf.

Exchange of Letters between the European Union and the Government of Kenya on the conditions and modalities for the transfer of persons suspected of having committed acts of piracy and detained by the European Union-led naval force (EUNAVFOR), and seized property in the possession of EUNAVFOR, from EUNAVFOR to Kenya and for their treatment after such transfer, EUR-lex, 2009, http://eur-lex.europa.eu/LexUriServ/LexUriServ.do?uri=OJ:L:2009:079:0049:0059:EN:PDF.

Fighting pirates in EU operation, Norway mission to the EU, 2009, http://www.eu-norway.org/news1/frigate/. Javier SOLANA, EU High Representative for the CFSP, congratulates Rear Admiral HUDSON on taking office as EU Operation Commander of Operation EU NAVFOR - ATALANTA, Rada Unii Europejskiej, 2009, http://www.consilium.europa.eu/uedocs/cms_data/docs/pressdata/EN/declarations/108239.pdf.

Pirates capture Spanish fishing vessel, Rada Unii Europejskiej, 2009, http://www.consilium.europa.eu/App/Article/Article.aspx?article_id=317\&page_id=1518\&type=1\&lang=en\&id=1567.

Political and security committee decision Atalanta 1/2008, EUR-lex, 2008, http://eur-lex.europa.eu/LexUriServ/LexUriServ.do?uri=OJ:L:2008:317:0024:0024:EN:PDF.

Resolution 1816 (2008), Rada Unii Europejskiej, 2008, http://www.consilium.europa.eu/uedocs/cmsUpload/N0836177.pdf.

Resolution 1851 (2008), Rada Unii Europejskiej, 2008, http://www.consilium.europa.eu/uedocs/cmsUpload/N0865501.pdf.

Somalia, U.S. Department of State Diplomacy In Action, 2010, http:/www.state.gov/r/pa/ei/bgn/2863.htm.

\section{Summary}

The uncontrollable outbreak of piracy attacks off the Somali coast has lately made the East African coast the area where the majority of all global maritime crimes occur. Located in East Africa, Somalia borders one of the most important maritime communication routes on Earth: 
the Suez Canal - the Red Sea - the Gulf of Aden. EU states could be acutely affected by the disruption of sea trade in this area, therefore they have become actively involved in fighting piracy off the Somali coast. As a result of political, organizational and legal activity, the Council of the EU established the first maritime military operation under the auspices of the European Union - EUNAVFOR Somalia - Operation Atalanta. The efficient operation of EU naval forces, hundreds of miles from European shores would not have been possible had it not been for an extensive and comprehensive maritime policy. Not only has its implementation enabled the EU to chase pirates in the Somali basin, or helped bring any criminals detained before the courts, but is has also influenced countries outside the European Union. 